\title{
Nursing diagnoses in the hemodynamics sector: an adaptive perspective
}

\author{
Diagnósticos de enfermagem no setor de hemodinâmica: uma perspectiva adaptativa \\ Diagnósticos de enfermería en el sector de hemodinámica: una perspectiva adaptativa
}

\author{
Angela Antonia Sartori ${ }^{1}$, Mari Ângela Gaedke ${ }^{1,2}$, André Carlos Moreira ${ }^{3}$, Murilo dos Santos Graeff ${ }^{4}$
}

How to cite this article:

Sartori AA, Gaedke MA, Moreira AC, Graeff MS. Nursing diagnoses in the hemodynamics sector: an adaptive perspective. Rev Esc Enferm USP. 2018;52:e03381. DOI: http://dx.doi.org/10.1590/S1980-220X2017006703381

\author{
1 Hospital de Santa Cruz, Programa de \\ Residência Multiprofissional em Saúde, \\ Santa Cruz do Sul, RS, Brazil. \\ 2 Universidade de Santa Cruz do Sul, \\ Departamento de Enfermagem e Odontologia, \\ Santa Cruz do Sul, RS, Brazil. \\ 3 Hospital Santa Cruz, Centro de \\ Terapia Endovascular - Hemodinâmica, \\ Santa Cruz do Sul, RS, Brazil. \\ 4 Rede de Saúde Divina Providência, \\ Porto Alegre, RS, Brazil.
}

\begin{abstract}
Objective: To identify nursing diagnoses of NANDA-I Taxonomy II in patients treated in the Hemodynamics Sector. Method: A descriptive, cross-sectional study with a quantitative approach conducted in a teaching hospital in the interior of Rio Grande do Sul. Data were collected through a sociodemographic characterization instrument and information regarding the problems of physical-physiological adaptation. Results: 100 patients participated in the study. Defining characteristics, risk factors and related factors were identified through adaptation problems. In all, 28 nursing diagnoses were identified, and 13 were considered for the discussion which presented frequency above $50 \%$ and represented the main adaptive problems. Protection, neurological and activity and rest components were the most frequent. Conclusion: The recognition of nursing diagnoses facilitates a connection between the main problems of adaptation and nursing interventions.
\end{abstract}

\section{DESCRIPTORS}

Nursing Diagnosis; Cardiology; Nursing Care; Cardiovascular Nursing. 


\section{INTRODUCTION}

Cardiovascular diseases are globally recognized as the leading cause of death, annually accounting for more than 17 million deaths (30\% of all deaths), $80 \%$ of which occur in low- and middle-income countries. Ischemic heart disease, which mainly consists of coronary artery disease, causes $46 \%$ of cardiovascular deaths in men and $38 \%$ in women ${ }^{(1)}$. Atherosclerosis, the underlying process that results in coronary disease, usually has a silent evolution over the years, so early diagnosis is important and an active search through diagnostic methods. Early diagnosis greatly depends on the way of life of the population and the access they have to health services. However, in our reality it is observed that many individuals will present an acute condition, with a high risk of death ${ }^{(2)}$.

In this context, nursing care is essential for the recovery of an individual afflicted by cardiovascular disease or when they undergo invasive procedures ${ }^{(3)}$. To that end, nursing has sought to improve its field of action based on scientific methodology, such as the Systematization of Nursing Care (SNC), which is a method of organization of nursing work ${ }^{(3-4)}$.

Systematizing nursing care involves implementing the Nursing Process. This process consists in the nurse defining the patient's problem, and will then establish a detailed care plan that must be properly implemented and documented. The nursing process is a work method which strives to be an assistance tool in professional practice and could be applied in any nursing professional activity ${ }^{(5)}$.

Nursing diagnoses (ND), the second phase of the nursing process, are clinical evaluations of individuals' responses to health problems, which may guide nursing interventions, direct care and encourage the patient to participate in their treatment, contributing to achieving the results, to which nurses respond ${ }^{(4-6)}$. Thus, special nursing jargon such as the nursing diagnostics taxonomy developed by NANDA International (NANDA-I), form the foundation of the profession's practice standardization, pointing out areas that contribute to nursing in this care setting ${ }^{(7)}$.

The Roy Adaptation Model ${ }^{(8)}$, adopted as the theoretical basis of this research, is subdivided into four adaptive modes, and the physical-physiological mode was used in this study. This mode corresponds to the individual's response as a physical being to environmental stimuli from the five basic needs (oxygenation, nutrition, elimination, activity and rest, and protection) and the four complex processes (feelings, fluids and electrolytes, neurological function and endocrine function $)^{(8)}$.

It is considered that identifying the nursing diagnoses of patients assisted in the hemodynamics sector may qualify the care, since in addition to helping in forming a care plan through applying the Nursing Process, it will provide patient safety and autonomy to the team. Additionally, even though the proposal of this study has already been previously developed in a similar way ${ }^{(9)}$, collecting new information about the same population in another scenario enables improvement of nursing care and a revision of the ND according to the NANDA-I.

From this scenario, this study aimed to identify the nursing diagnoses of NANDA-I Taxonomy II in patients attended to in the hemodynamics sector.

\section{METHOD}

\section{STUdY TYPE}

A cross-sectional and descriptive study with a quantitative approach was carried out.

\section{SCENARIO}

The research was developed in the hemodynamics sector of a teaching hospital in the interior of Rio Grande do Sul, a reference hospital of high cardiovascular complexity in the Vales region.

Sampling was defined by consecutive convenience, and consisted of 100 patients admitted to the hemodynamics sector and submitted to diagnostic or therapeutic procedures. The inclusion criteria were: patients of both genders, aged 18 years or older, conscientious and able to respond in the interview, who were admitted to the hemodynamics sector from Monday to Friday between 07:00 a.m. to 19:00h to perform a diagnostic or therapeutic procedure. Similar criteria were used in a previous study ${ }^{(9)}$.

\section{Data collection}

Data collection was performed by nursing researchers during the months of July and August of 2016, via a specific anamnesis and physical examination instrument divided into sociodemographic, clinical characterization data and changes in the physical-physiological mode of Roy's Adaptation Model ${ }^{(8)}$. This was subdivided into five basic needs (oxygenation, nutrition, elimination, activity and rest, protection) and complex processes (feelings, fluids and electrolytes, and neurological function). The patients were approached regarding the study either before or after performing the procedures.

In order to characterize the sample, the following sociodemographic/clinical variables were used: gender, age (categorized as 20 in 20 years), marital status (individuals living with or without a partner), skin color (white, brown or black), schooling (incomplete primary education, elementary school, high school or higher education), occupation (active worker, retired or unemployed), origin (Santa Cruz do Sul or other cities), comorbidities (hypertension, diabetes, congestive heart failure, chronic renal failure, dyslipidemia), body mass index (BMI) classification (obesity, overweight 
or normal weight) and performed procedures (cardiac catheterization, coronary angioplasty, electrophysiological study, peripheral angioplasty, pacemaker implantation).

\section{DATA ANALYSIS AND PROCESSING}

The collected information was compiled into a database, and the Statistical Package for Social Sciences (SPSS) version 23.0 software (IBM, Armonk, NY, USA) and Microsoft Excel program were used. A descriptive analysis of the collected variables was performed (all categories) which were expressed in absolute and relative frequency. After identifying the defining characteristics, related factors and more prevalent risk factors in this population by NANDA-I Taxonomy II, sociodemographic/clinical characterization and the data collected in relation to the physical-physiological adaptation problems, the NDs were then selected in three stages. First, a list of 28 possible NDs were identified from the search of the defining characteristics and risk factors in this taxonomy, and those with a frequency greater than $50 \%$ were established as the cut-off point for analysis. In the second stage, the most frequent NDs were validated for the study population through clinical reasoning and critical thinking according to recommended nursing care methodology, based on the analysis of the physiological adaptive mode. This step was independently performed by two nurses with expertise in this theme, and any divergent validations were decided by consensus between them. The third step was to calculate the prevalence of each validated ND from the frequency of defining characteristics and risk factors found in each ND. Nursing diagnoses were classified according to domains and classes of the NANDA-I Taxonomy II.

\section{ETHICAL ASPECTS}

The study was approved by the Research Ethics Committee of the Universidade de Santa Cruz do Sul, Report No. 1.625.420. The ethical precepts of Resolution 466/2012 of the National Health Council were respected, and all study participants signed a clear and Informed Consent Form.

\section{RESULTS}

One hundred (100) patients participated in the study. Regarding the sample characterization, it was observed that $55 \%$ of the interviewees were male in the age group of 30 to 90 years, with a predominance in the age group from 50 to $69(60 \%)$, which corresponds to an average age of 64.56 years. There was a predominance of white people (86\%) who lived with a companion (78\%). There was also low schooling in the sample, where $47 \%$ studied until elementary school, and most were retired (57\%). It was also observed that about half of the patients came from municipalities in the region, which is justified by the fact that the institution of the study scenario is the reference center for the region.

It was identified that the majority of subjects had more than one associated comorbidity, emphasizing systemic arterial hypertension (85\%), dyslipidemia (49\%) and diabetes mellitus (30\%). Regarding body mass index, 53\% of the participants were overweight according to the classifications described by the World Health Organization ${ }^{(10)}$. Regarding the type of procedure performed, 64\% underwent cardiac catheterization and $21 \%$ underwent percutaneous transluminal coronary angioplasty.

According to the data collection instrument used to investigate the main problems of physiological adaptation ${ }^{(8)}$, it was possible to identify the main defining characteristics, risk factors and related factors that resulted in identifying the nursing diagnoses through clinical reasoning and diagnostic judgment. Likewise, the most prevalent nursing diagnoses were described and associated with the components (basic needs) and the complex processes of the physiological mode in Roy's Adaptation Model.

Thus, 28 nursing diagnoses (Table 1), with a relative frequency between $15 \%$ and $100 \%$ were identified, which were divided into two groups. The first was represented by NDs with a frequency below 50\%, and the second by 13 NDs with a frequency of more than 50\%. Five of these were risk diagnoses: Risk for infection, Risk for impaired cardiovascular function, Risk for bleeding, Risk for adverse reaction to iodinated contrast media, Risk for decreased cardiac tissue perfusion; and eight diagnoses were focused on the problem: Overweight, Decreased cardiac output, Ineffective peripheral tissue perfusion, Activity intolerance, Impaired verbal communication, Impaired walking, Acute pain, and Impaired physical mobility. The second group was chosen to represent the studied sample with a cut-off point of 50\%, and all 13 diagnoses were validated by consensus among specialists in order to represent the main adaptive problems found in patients with cardiovascular diseases treated in the hemodynamics sector.

Through the changes found in the study population, it was possible to gain knowledge and relate the physiological/ physical-physiological findings according to Roy's Model, as shown in Table 1.

When analyzing the diagnoses, it was observed that the need for protection was the group that presented the highest number of diagnoses (8), followed by neurological (4), activity and rest (4), oxygenation (3), feelings (3), liquid, electrolytes and acid-base balance (2), nutrition (2) and eliminations (2). Only the complex process of endocrine function did not present diagnoses, since it was not contemplated in the data collection instrument. The discussion of the main NDs was expanded, relating them to their defining characteristics, related factors and risk factors, as described in Table 2. 
Table 1 - Nursing diagnoses identified in patients submitted to a diagnostic or therapeutic procedure in the Hemodynamic Sector Santa Cruz do Sul, RS, Brazil, 2016.

\begin{tabular}{|c|c|c|}
\hline Nursing diagnoses by components and complex processes & $\mathbf{N}$ & $\%$ \\
\hline \multicolumn{3}{|l|}{ Oxygenation } \\
\hline Decreased cardiac output (00029) & 70 & 70 \\
\hline Ineffective breathing pattern (00032) & 33 & 33 \\
\hline Impaired gas exchange (00030) & 25 & 25 \\
\hline \multicolumn{3}{|l|}{ Protection } \\
\hline Risk for infection (00004) & 100 & 100 \\
\hline Risk for adverse reaction to iodinated contrast media (00218) & 90 & 90 \\
\hline Impaired skin integrity (00046) & 46 & 46 \\
\hline Impaired Comfort (00214) & 45 & 45 \\
\hline Ineffective protection $(00043)$ & 41 & 41 \\
\hline Risk for pressure ulcer (00249) & 38 & 38 \\
\hline Impaired Dentition (00048) & 32 & 32 \\
\hline Risk for allergic reaction $(00217)$ & 15 & 15 \\
\hline \multicolumn{3}{|l|}{ Senses } \\
\hline Impaired verbal communication (00051) & 55 & 55 \\
\hline Impaired walking (00088) & 53 & 53 \\
\hline Acute pain (00132) & 53 & 53 \\
\hline \multicolumn{3}{|l|}{ Liquids, electrolytes and basic acid balance } \\
\hline Ineffective peripheral tissue perfusion (00204) & 65 & 65 \\
\hline Excess fluid volume (00026) & 31 & 31 \\
\hline \multicolumn{3}{|l|}{ Neurological } \\
\hline Fear (00148) & 35 & 35 \\
\hline Anxiety (00146) & 34 & 34 \\
\hline Risk for powerlessness (00152) & 27 & 27 \\
\hline Risk for acute confusion (00173) & 16 & 16 \\
\hline \multicolumn{3}{|l|}{ Nutrition } \\
\hline Overweight (00233) & 77 & 77 \\
\hline Obesity (00232) & 50 & 50 \\
\hline \multicolumn{3}{|l|}{ Elimination } \\
\hline Risk for bleeding (00206) & 100 & 100 \\
\hline Impaired urinary elimination (00016) & 21 & 21 \\
\hline \multicolumn{3}{|l|}{ Activity and rest } \\
\hline Risk of impaired cardiovascular function (00239) & 100 & 100 \\
\hline Risk for decreased cardiac tissue perfusion (00200) & 85 & 85 \\
\hline Activity Intolerance (00092) & 57 & 57 \\
\hline Impaired physical mobility (00085) & 50 & 50 \\
\hline
\end{tabular}

Table 2 - Association of Nursing Diagnoses most frequently present in patients submitted to diagnostic or therapeutic procedures in the Hemodynamics Sector - Santa Cruz do Sul, RS, Brazil, 2016.

\begin{tabular}{|c|c|c|c|c|}
\hline Nursing diagnosis & Defining characteristics & $\%$ & Related or risk factors & $\%$ \\
\hline Risk for infection & & & Invasive procedure & 100 \\
\hline $\begin{array}{l}\text { Risk of impaired cardiovascular } \\
\text { function }\end{array}$ & & & History of cardiovascular disease & 100 \\
\hline Risk for bleeding & & & Treatment regimen & 100 \\
\hline $\begin{array}{l}\text { Risk for adverse reaction to } \\
\text { iodinated contrast media }\end{array}$ & & & Contrast media precipitates adverse event & 90 \\
\hline $\begin{array}{l}\text { Risk for decreased cardiac tissue } \\
\text { perfusion }\end{array}$ & & & Coronary Artery Spasm & 85 \\
\hline
\end{tabular}




\begin{tabular}{|c|c|c|c|c|}
\hline \multicolumn{5}{|l|}{...continuation } \\
\hline Nursing diagnosis & Defining characteristics & $\%$ & Related or risk factors & $\%$ \\
\hline Impaired walking & Impaired ability to walk the required distances & 16 & Insufficient muscle strength & 37 \\
\hline Impaired physical mobility & Slowed Movements & 16 & Activity Intolerance & 34 \\
\hline \multirow[t]{2}{*}{ Acute pain } & \multirow[t]{2}{*}{ Self-reported intensity using } & \multirow[t]{2}{*}{03} & Physical injury agent & 29 \\
\hline & & & Biological injury agent & 21 \\
\hline \multirow[t]{3}{*}{ Decreased cardiac output } & Decreased in peripheral pulses & 21 & \multirow[t]{3}{*}{ Alteration in heart rhythm } & \multirow[t]{3}{*}{25} \\
\hline & Edema & 14 & & \\
\hline & Abnormal skin color & 10 & & \\
\hline Overweight & High BMI & 53 & $\begin{array}{l}\text { Average daily physical activity is less than } \\
\text { recommended for gender and age }\end{array}$ & 24 \\
\hline \multirow[t]{2}{*}{ Activity intolerance } & Exertional Dyspnea & 17 & Physical deconditioning & 16 \\
\hline & Fatigue & 16 & Immobility & 08 \\
\hline \multirow{3}{*}{$\begin{array}{l}\text { Ineffective peripheral tissue } \\
\text { perfusion }\end{array}$} & Decreased in peripheral pulses & 21 & \multirow{3}{*}{$\begin{array}{l}\text { Insufficient knowledge of modificable } \\
\text { factors }\end{array}$} & \multirow[t]{3}{*}{14} \\
\hline & Changed motor function & 16 & & \\
\hline & Edema & 14 & & \\
\hline \multirow[t]{3}{*}{ Impaired verbal communication } & Difficulty comprehending communication & 20 & Emotional disturbances & 13 \\
\hline & Difficult speaking & 09 & \multirow[t]{2}{*}{ Physical barrier } & \multirow[t]{2}{*}{05} \\
\hline & Difficulty in selective attending & 08 & & \\
\hline
\end{tabular}

\section{DISCUSSION}

Cardiovascular diseases have been the main cause of death and are responsible for the high hospitalization frequency. Much progress has been made in relation to treating coronary diseases, and the percutaneous approach is an increasingly prevalent intervention. In this context, patient care is performed by a multidisciplinary team, and nurses play an important role in care, since it is the professional who assists the patient throughout his or her hospital stay ${ }^{(10)}$.

By prioritizing comprehensive care from a holistic view of the individual, Nursing treats the human responses to health conditions and life processes, or a vulnerability to such a response, thus identifying health problems and a state of risk $^{(6)}$. Diagnostic indicators are identified based on the characteristics found in the anamnesis and the physical examination, which include defining characteristics and related factors to compose NDs with a focus on the problem as well as vulnerabilities, which indicate the risk diagnoses. It should be emphasized that the diagnostic phase is the guideline to obtain results which are sensitive to nursing interventions.

In this study, the diagnosis Risk for infection was predominant, having the performance of invasive procedures as a risk factor with the same statistical frequency. Another similar study also showed a predominance of this diagnosis in their sample, possibly being related to the fact that patients are submitted to invasive procedures, so that the vast majority of those hospitalized will present a risk for infection, especially if they undergo a surgical procedure ${ }^{(11)}$.

Another predominant diagnosis was Risk for bleeding, defined as "vulnerability to a reduction of blood volume that may compromise health" ${ }^{(6)}$. According to a study performed in a hemodynamic laboratory of a university hospital in the Metropolitan Region of Rio Grande do Sul, Brazil, with patients undergoing cardiac catheterization, "bleeding at the puncture site was observed as the second vascular complication" ${ }^{\prime(2)}$. Another study conducted in 47 hospitals in all Brazilian regions analyzed the occurrence of adverse cardiovascular events in patients submitted to angioplasty according to the arterial access route, finding severe bleeding in $1.1 \%$ of the sample, with no statistical difference between the radial and femoral pathways ${ }^{(13)}$.

The diagnosis Risk of impaired cardiovascular function is defined as "vulnerability to internal or external causes that can damage one or more vital organs or the circulatory system"(6). Identifying this diagnosis is related to changes in cardiovascular function. The results of a study performed in the coronary unit of the Federal University of São Paulo school hospital with all hypertensive patients, and a majority with dyslipidemia and diabetes, showed a relation between acute coronary syndrome and cardiovascular risk factors ${ }^{(14)}$.

The diagnosis Risk for adverse reaction to iodinated contrast media is defined as "vulnerability to a harmful or unintentional response associated with the use of iodine contrast medium, which may occur within 7 days after contrast medium injection, which can compromise health"(6). A study carried out in a teaching hospital in Curitiba, Paraná state ${ }^{(15)}$ identified the same nursing diagnoses in patients undergoing cardiac catheterization as in the present study. In another study conducted in French hospitals with patients who had image-guided cardiovascular interventions requiring contrast administration, 3.1\% of hospitalizations were due to acute kidney injury, being the third 
cause of hospitalization ${ }^{(16)}$. Thus, it is important to identify this risk for establishing a care plan aimed at preventing complications to which patients are exposed when using contrast medium.

The diagnosis Impaired verbal communication is defined as diminished, delayed, or absent verbal ability ${ }^{(6)}$, and in the present study the difficulty of understanding communication, speaking and selective attention were the defining characteristics. Such alterations may be partly explained by the predominantly older adult sample, since these constitute common changes in this age group. This diagnosis requires that nurses take a careful look at developing interventions that promote more effective communication between staff and patients, since patients in this unit will receive many care guidelines, as well as frequently need to communicate their health complaints to the team.

Decreased cardiac output is among the major adaptive problems found in the study, and can be defined as "insufficient amount of blood pumped by the heart to meet the body's metabolic demands" ${ }^{(6)}$. The defining characteristics of the signs and symptoms presented by the patients were abnormal skin color, edema and diminished peripheral pulses. Therefore, cardiovascular problems may alter myocardial function, thereby causing repercussions on cardiac output ${ }^{(7)}$.

The risk for decreased cardiac tissue perfusion is defined as "vulnerability to reduced cardiac (coronary) circulation that may compromise health"(6); a diagnosis identified from the clinical data of patients at risk of blood flow interruption, such as those with acute myocardial infarction, coronary insufficiency and unstable angina. Acute myocardial infarction occurs "in non-specific heart regions, and the most frequent cause is related to blood flow interruption through coronary artery narrowing," which may occur by obstruction of the artery by thrombus, atherosclerosis, or blood $\operatorname{clot}^{(17)}$.

The diagnosis Acute pain was identified by chest complaints, when the patients reported precordial or retrosternal pain, and had the surgical procedure as a related factor. Precordial pain and anxiety present in myocardial ischemic syndromes usually cause sympathetic nervous system hyperactivity, and may cause increased oxygen consumption in the cardiac muscle ${ }^{(18)}$.

High BMI is a recognized risk factor for cardiovascular diseases, and was evidenced in a large proportion of the sample, while an overweight nursing diagnosis was also identified in these patients. A significant number of patients were obese and also had abnormal lipids, high triglycerides, were associated with smoking, hypertension, diabetes, abdominal obesity, and psychosocial stress; factors which represent a risk of acute myocardial infarction ${ }^{(19)}$.

In order to prevent a potential problem, identifying the main NDs in this sample enables nurses to use interventions to reduce the impact of the risks, thus contributing to better patient adaptation ${ }^{(9)}$.

The Nursing Process allows the nurse to organize their professional work in a dynamic and systematic way, thus enabling them to attend to the real health needs of the patients. In addition, it is a process that favors identifying the necessary team for implementing care and interrelates their actions, also making it possible to identify qualification and improvement needs $s^{(7,20)}$.

In a study conducted in Fortaleza, Ceará state, Brazil( ${ }^{(9)}$, which also sought to identify "nursing diagnoses in patients with coronary disease treated in a Hemodynamic Laboratory, in light of the physico-physiological mode of Roy's adaptation model", the results were similar to those in the present study. The main diagnoses were Risk of infection and risk of bleeding. However, as a result of NANDA-I updates, it was not possible to identify important diagnoses with better accuracy for the patients' profiles, such as the diagnosis of impaired cardiovascular function risk (inserted in 2013) and the Risk of adverse response to iodine contrast medium (inserted in 2010-2013).

\section{CONCLUSION}

In performing this study it was possible to identify sociodemographic and clinical characteristics, the defining characteristics, the risk factors, the related factors and the nursing diagnoses through the adaptation problems of the physiological mode. ND recognition facilitates the link between the main adaptation problems and nursing interventions.

The use of the physiological adaptation model enabled identifying $28 \mathrm{NDs}$ of the patients treated in the hemodynamic sector, and 13 of which were considered for the discussion, which represented the main adaptive problems. The most frequent were those of protection, neurological and activity and rest components, which assisted in providing in-depth knowledge of the health and disease vulnerability situation during the procedures. Thus, nursing has the crucial role of identifying these signs and symptoms in care to develop a care plan that addresses the real needs, so as to make the care individualized.

With the presented results, it will be possible to plan specific care for patients submitted to invasive procedures in the hemodynamics sector, as well as to organize nursing care in order to optimize team time and improve the care quality, thereby reducing injury and health risks to patients.

The nurses in the institution where the study was performed did not perform all stages of the Nursing Process; therefore, by conducting this research it was possible to collaborate to improve nursing professionals, encouraging them to perform Nursing Care Systematization with views to improving care. 
RESUMO

Objetivo: Identificar os diagnósticos de enfermagem da Taxonomia II da NANDA-I em pacientes atendidos no Setor de Hemodinâmica. Método: Estudo descritivo, transversal, com abordagem quantitativa, realizado em um Hospital de Ensino do interior do Rio Grande do Sul. Os dados foram coletados por intermédio de um instrumento de caracterização sociodemográfica e informações referentes aos problemas de adaptação do modo físico-fisiológico. Resultados: Participaram do estudo 100 pacientes. Foram identificados as características definidoras, os fatores de risco e os fatores relacionados por meio dos problemas de adaptação. No total, identificaram-se 28 diagnósticos de enfermagem, e para a discussão foram considerados 13 , os quais apresentaram frequência acima de $50 \%$ e representaram os principais problemas adaptativos. Os componentes proteção, neurológico e atividade e repouso foram os mais frequentes. Conclusão: O reconhecimento dos diagnósticos de enfermagem facilita a ligação entre os principais problemas de adaptação e as intervenções de enfermagem.

\section{DESCRITORES}

Diagnóstico de Enfermagem; Cardiologia; Cuidados de Enfermagem; Enfermagem Cardiovascular.

\section{RESUMEN}

Objetivo: Identificar los diagnósticos de enfermería de la Taxonomía II de NANDA-I en pacientes atendidos en el Sector de Hemodinámica. Método: Estudio descriptivo, transversal, con abordaje cuantitativo, llevado a cabo en un Hospital de Enseñanza del interior de Río Grande do Sul. Los datos fueron recogidos por intermedio de un instrumento de caracterización sociodemográfica e informaciones referentes a los problemas de adaptación del modo físico fisiológico. Resultados: Participaron en el estudio 100 pacientes. Fueron identificadas las características definidoras, los factores de riesgo y los factores relacionados mediante los problemas de adaptación. En total, se identificaron 28 diagnósticos de enfermería, y para la discusión fueron considerados 13, los que presentaron frecuencia superior al $50 \%$ y representaron los principales problemas adaptativos. Los componentes protección, neurológico y actividad y reposo fueron los más frecuentes. Conclusión: El reconocimiento de los diagnósticos de enfermería facilita la conexión entre los principales problemas de adaptación y las intervenciones enfermeras.

\section{DESCRIPTORES}

Diagnóstico de Enfermería; Cardiología; Atención de Enfermería; Enfermería Cardiovascular.

\section{REFERENCES}

1. World Health Organization. Global atlas on cardiovascular disease prevention and control [Internet]. Geneva: WHO; 2011 [cited 2018 May 06]. Available from: http://www.who.int/cardiovascular_diseases/publications/atlas_cvd/en/

2. Cesar LA, Ferreira JF, Armaganijan D, Gowdak LH, Mansur AP, Bodanese LC et al. Guideline for stable coronary artery disease. Arq Bras Cardiol [Internet]. 2014 [cited 2018 May 06];103(2 Suppl 2):1-59. Available from: http://www.scielo.br/pdf/abc/v103n2s2/0066-782Xabc-103-02-s2-0001.pdf

3. Ribeiro CP, Silveira CO, Benetti ERR, Gomes JS, Stumm EMF. Diagnósticos de enfermagem em pacientes no pós-operatório de cirurgia cardíaca. Rev RENE [Internet]. 2015 [citado 2016 dez. 05];16(2):159-67. Disponível em: http://repositorio.ufc.br/bitstream/ riufc/12644/1/2015_art_cpribeiro.pdf

4. Tannure MC, Pinheiro AM. SAE - Sistematização da Assistência de Enfermagem: guia prático. São Paulo: Guanabara Koogan; 2011.

5. Oliveira RG. Blackbook: enfermagem. Belo Horizonte: Blackbook; 2016.

6. NANDA International. Diagnósticos de enfermagem da NANDA: definições e classificação 2015-2017. Porto Alegre: Artmed; 2015.

7. Ferreira AM, Rocha EN, Lopes CT, Bachion MM, Lopes JL, Barros ALBL. Diagnósticos de enfermagem em terapia intensiva: mapeamento cruzado e Taxonomia da NANDA-I. Rev Bras Enferm [Internet]. 2016 [citado 2016 dez. 05];69(2):285-93. Disponível em: http://www. scielo.br/pdf/reben/v69n2/0034-7167-reben-69-02-0307.pdf

8. Roy C. Roy adaptation model: Sister Callista Roy. In: Masters K. Nursing theories: a framework for professional practice [Internet]. Mississippi: Jones \& Bartlett ; 2014 [cited 2017 Dec 20]. Available from: http://samples.jbpub.com/9781449626013/72376_CH10_Masters.pdf

9. Oliveira MF, Silva LF. Enfermagem em laboratório de hemodinâmica: diagnóstico e intervenção fundamentados na Teoria da Adaptação de Roy. Rev Eletr Enf [Internet]. 2010 [citado 2016 dez. 10];12(4):678-85. Disponível em: https://www.fen.ufg.br/fen_revista/v12/n4/pdf/ v12n4a12.pdf

10. Colósimo F, Sousa A, Silva G, Piotto R, Pierin A. Arterial hypertension and associated factors in patients submitted to myocardial revascularization. Rev Esc Enferm USP [Internet]. 2015 [cited 2016 Feb 02];49(2):201-7. Available from: http://scielo.br/pdf/reeusp/ v49n2/0080-6234-reeusp-49-02-0201.pdf

11. Vasconcelos AC, Castro CGA, Silva DF, Sousa VJ. Frequência de diagnósticos de enfermagem em uma clínica cirúrgica. Rev RENE [Internet]. 2015 [citado 2018 maio 04]; 16(6):826-32. Disponível em: http://repositorio.ufc.br/bitstream/riufc/14767/1/2015_art_acvasconcelos.pdf

12. Matte R, Hilário TS, Reich R, Aliti GB, Rabelo-Silva ER. Reducing bed rest time from five to three hours does not increase complications after cardiac catheterization: the THREE CATH Trial. Rev Latino Am Enfermagem [Internet]. 2016 [cited 2016 Dec 05]. Available from: http://www.scielo.br/scielo.php?script=sci_arttext\&pid=S0104-11692016000100346

13. Andrade $\mathrm{P}$, Andrade M, Barbosa R, Labrunie A, Hernandes M, Marino R, et al. Femoral versus radial access in primary angioplasty: analysis of the ACCEPT Registry. Arq Bras Cardiol [Internet]. 2014 [cited 2016 Dec 05]. Available from: http://www.scielo.br/scielo.php?script=sci_ arttext\&pid=S0066-782X2014000600006

14. Brunori EHFR, Lopes CT, Cavalcante AMRZ, Santos VB, Lopes JL, Barros ALBL. Association of cardiovascular risk factors with the different presentations of acute coronary syndrome. Rev Latino Am Enfermagem [Internet]. 2014 [cited 2018 May 06];22(4):538-46. Available from: http://www.scielo.br/scielo.php?script=sci_arttext\&pid=S0104-11692014000400538

15. Aquino EM, Roehrs H, Méier MJ. Diagnósticos de enfermagem em pacientes submetidos a cateterismo cardíaco em uma unidade de cardiologia. Rev Enferm UFPE [Internet]. 2014 [citado 2018 maio 06]; 8(11):3929-37. Disponível em: https://periodicos.ufpe.br/revistas/ revistaenfermagem/article/download/13617/16454 
16. Aubry P, Brillet G, Catella L, Schmidt A, Bénard S. Outcomes, risk factors and health burden of contrast-induced acute kidney injury: an observational study of one million hospitalizations with image-guided cardiovascular procedures. BMC Nephrol [Internet]. 2016 [cited 2016 Dec 20]; 17(1). Available from: http://bmcnephrol.biomedcentral.com/articles/10.1186/s12882-016-0385-5

17. Siervuli MTF, Silva AS, Silva AC, Muzzi RAL, Santos GAB. Infarto do miocárdio: alterações morfológicas e breve abordagem da influência do exercício físico. Rev Bras Cardiol. 2014;27(5):349-55.

18. Feitosa-Filho G, Baracioli L, Barbosa C, Franci A, Timerman A, Piegas L et al. SBC Guidelines on unstable angina and non-ST-elevation myocardial infarction: executive summary. Arq Bras de Cardiol [Internet]. 2015 [cited 2016 Dec 10];105(3). Available from: http://www. scielo.br/scielo.php?script=sci_arttext\&pid=S0066-782X2015002200214

19. Agrawal V, Lohiya BV, Sihag BK, Prajapati R. Clinical profile with angiographic correlation in naïve acute coronary syndrome. J Clin Diagn Res. 2016;10(9):OC10-4.

20. Medeiros AL, Santos SR, Cabral RWL, Silva JPG, Nascimento NM. Avaliando diagnósticos e intervenções de enfermagem no trabalho de parto e na gestação de risco. Rev Gaúcha Enferm [Internet]. 2016 [citado 2017 set. 05];37(3):e55316. Disponível em: http://www.scielo. br/pdf/rgenf/v37n3/0102-6933-rgenf-1983-144720160355316.pdf 